\title{
Solid-Phase Synthesis of Photochromic Spiropyrans
}

Key Words

photochromic spiropyrans indolines

library<smiles>C=C1N(C)c2ccc(NC(=O)CCC(=O)OCc3ccccc3)cc2C1(C)C</smiles><smiles>O=Cc1ccccc1O</smiles><smiles>CN1c2ccc(NC(=O)CCC(=O)OCc3ccccc3)cc2C(C)(C)C12C=Cc1ccccc1O2</smiles>
$\underset{\mathrm{THF}}{\stackrel{\text { tBuOK }(15 \mathrm{~mol} \%)}{\longrightarrow}}$<smiles>CN1c2ccc(N3C(=O)CCC3=O)cc2C(C)(C)C12C=Cc1ccccc1O2</smiles>

Significance: A 23-membered photochromic spiropyrans library was prepared via solid-phase synthesis. An indoline derivative was anchored onto the Wang resin by a succinate linker. Reaction of the supported indoline $\mathbf{1}$ with various salicylaldehydes $\mathbf{2}$ gave the corresponding resinbound spiropyrans $\mathbf{3}$. The resin-bound spiropyrans were cleaved from solid phase with a catalytic amount of $t$-BuOK to afford excellent yields of succinimidospiropyrans (82-100\%).
Comment: Spiropyrans have been extensively studied (R. Guglielmetti In Photochromism: Molecules and Systems; H. Dürr, H. Bouas-Laurent, Eds.; Elsevier: Amsterdam, 1990, pp 314-466). Solid-phase synthesis of photochromic spiropyrans was reported for the first time. 